\title{
Evaluation of the Potential Anti-inflammatory Effects of Endoparasitoid Pimpla turionellae L. (Hymenoptera: Ichneumonidae) venom on Mammalian Cell Lines
}

\author{
Hülya ALTUNTAŞ ${ }^{* 1}$, Sara VLEMINCKX ${ }^{2}$, Ellen DANNEELS ${ }^{2}$, Ekrem ERGIN $^{1}$, Dirk C. de GRAAF ${ }^{2}$ \\ ORCID: 0000-0003-4505-0098; 0000-0002-6974-5866; 0000-0002-2266-6298; \\ 0000-0001-7301-3783; 0000-0001-8817-0781
}

${ }^{1}$ Department of Biology, Faculty of Science, Eskisehir Technical University, Eskisehir, TURKEY

${ }^{2}$ Laboratory of Molecular Entomology and Bee Pathology, Department of Biochemistry and Microbiology, Faculty of Sciences, Ghent University, Ghent, BELGIUM

\begin{abstract}
Parasitic wasps inject their eggs, together with a complex venom mixture, in or on other insects. Parasitoid venoms use various mechanisms to manipulate the physiology and suppress the immune system of their hosts, thus enabling the growth and development of their offspring. Since the major mechanisms of innate immunity in insects are homologous to the Nuclear Factor kappa B (NF- $\kappa \mathrm{B})$ pathway in mammalian immunity, this study hypothesized that venom related immune suppression observed in host insects could also be observed in mammalian cells. Therefore, an NF- $\kappa \mathrm{B}-$ dependent luciferase assay was used to determine the effects of $P$. turionellae venom on murine fibrosarcoma L929sA cells. Results from an MTT assay showed that venom from P. turionellae has no cytotoxic effects on L929sA cell lines when considering a defined range of exposure time and concentrations. Also, the present study indicated that endoparasitoid $P$. turionellae venom has potential to inhibit NF- $\kappa \mathrm{B}$ signaling in cells of mammals at nontoxic concentrations. In conclusion, venom components from ecto- or endoparasitoid wasps have anti-inflammatory potential on increased immune responses of mammalian cells.
\end{abstract}

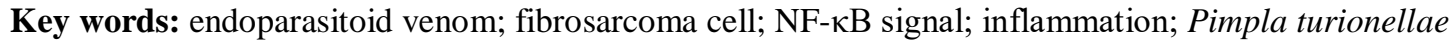

\section{Pimpla turionellae L. (Hymenoptera: Ichneumonidae) Zehirinin Memeli Hücrelerindeki Potansiyel Antienflamatuvar} Etkilerinin Değerlendirilmesi

\section{Özet}

Parazitik arılar sahip oldukları kompleks bir zehir karışımı ile birlikte yumurtalarını diğer böceklerin içine veya üzerine enjekte ederler. Parazitoidlerin zehirleri, genç parazitoidin büyüme gelişimini sağlamak amacıyla konak fizyolojisini değiştirecek veya bağışıklık sistemini baskılayacak şekilde iş görmektedir. Böceklerde başlıca doğal

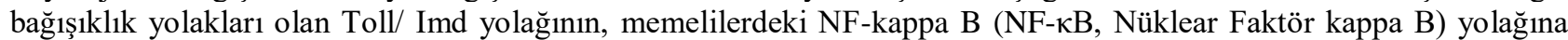
homolog olması nedeniyle, zehire bağlı olarak konak böceğin bağışıklık sisteminde oluşan tepkilerin memeli hücre sisteminde de olabileceği çalışmamızın hipotezi olarak belirlenmiştir. Bu nedenle, $P$. turionellae zehrinin murin fibrosarkoma L929sA hücreleri üzerindeki etkilerini belirlemek için NF- $\kappa B$ 'ye bağımlı bir lusiferaz aktivite testi kullanıldı. MTT testinden elde edilen sonuçlar, $P$. turionellae'den elde edilen zehirinin uygulanan inkübasyon sürelerinde ve konsantrasyonlarda L929sA hücre hatları üzerinde sitotoksik etkiye sahip olmadığını göstermiştir. Ayrıca, bu çalışma, endoparazitoit $P$. turionellae zehirinin, toksik olmayan konsantrasyonlarında memeli hücrelerindeki

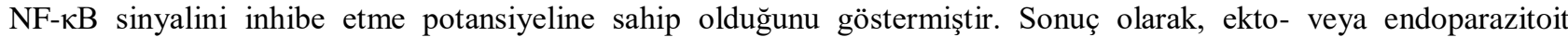

\footnotetext{
* Corresponding author / Haberleşmeden sorumlu yazar: Tel.: +902223350580/4706; Fax: +902223204910; E-mail: hyalcitas@eskisehir.edu.tr

(C) Copyright 2021 by Biological Diversity and Conservation $\quad$ Received: 14.12.2020; Published: 15.12.2021
} 
arılardan elde edilen zehir bileşenleri, memeli hücrelerinin artan bağışıklık tepkileri üzerinde antienflamatuvar potansiyele sahiptir.

Anahtar kelimeler: endoparazitoit zehir; fibrosarkoma hücre; NF-кB sinyal; enflamasyon; Pimpla turionellae

\section{Introduction}

Venom extracts of various animals were studied to determine their possible anti-inflammatory effects on different chronic inflammatory diseases (i.e atherosclerosis and rheumatoid arthritis) and cancer [1-4]. In this context, the research on parasitoid venoms for use as immune suppressing agents has become remarkable, because several peptides/proteins are produced in wide range and at high level in their venom glands. Endoparasitoids have immune regulation mechanisms to provide a suitable nutritional environment for the successful development of their offspring inside host insects [5-6]. These parasitism-dependent regulations of host immunity in particular idiobiont species are due to injection of maternal factors [7-9]. Several endoparasitoids have been proven to exert immune suppressive activity on their host [10]. This function is mostly attributed to the polydnavirusses (PDVs) that are simultaneously released with the parasitoid venom prior to oviposition. PDVs are known to suppress both humoral immunities, by interfering with melanization, AMP synthesis and the prophenoloxidase cascade, and cellular immunity, through inhibition of encapsulation, in the host organism [11-12]. However, like the ectoparasitoid wasp Nasonia vitripennis (Walker) (Hymenoptera: Pteromalidae), P. turionellae also lacks PDVs, indicating that all immune suppressive effects are likely carried out by venom components [4]. This shows that this endoparasitoid wasp (Hymenoptera: Ichneumonidae) is an interesting species to study anti-inflammatory potential of the venom compounds.

The idiobiont, endoparasitoid wasp Pimpla turionellae L. (Hymenoptera: Ichneumonidae) also injects its pupal host with venom during oviposition. Studies on the immune suppressive effect of $P$. turionellae venom have shown that it inhibits the immune system in its host organism in order to protect their offspring from elimination. Interestingly, as mentioned before, this wasp venom lacks polydnaviruses and virus-like particles so that the wasp venom is likely to play a major role in host regulation [13]. Venom from $P$. turionellae contains a number of biologically active components including proteins, peptides, and biogenic amines. Additionally, venom displays a mixture of several mid to high range molecular weight proteins [14]. Previous studies reported that depending on host susceptibility, $P$. turionellae venom exhibits cytotoxic and/or cytolytic mechanisms thus inducing host paralysis [9, 14]. Furthermore, venom-induced morphological changes were shown in the BTI-TN-5B1-4 and Aag-2 cell lines isolated from cabbage looper, Trichoplusia ni (Hübner) (Lepidoptera: Noctuidae) and larvae of the yellow fever mosquito, Aedes aegypti (L.) (Diptera: Culicidae), respectively. All these previous studies have focused on the host insect hemocyte immune responses following treatment with $P$. turionellae venom [15]. However, the promising recent findings reported by Danneels et al. [4] and Saba et al. [16] showed that the venom of two ectoparasitoid species N. vitripennis and Bracon hebetor Say (Hymenoptera: Braconidae) have anti-inflammatory potential on mammalian cells. It is known that the Toll and Imd pathways in insects are homologous to the mammalian Nuclear Factor kappa B (NF-kB pathway) [17] and studies show that even at molecular level of invertebrates and vertebrates, these innate immunity pathways are evolutionary conserved [18]. In mammalian organisms, various immune responses like inflammation are regulated by the NF- $\mathrm{KB}$ transcription factors [19]. Numerous diseases such as inflammatory and autoimmune diseases, septic shock, viral infection, abnormal immune development, and cancer are a result of the incorrect regulation or excess activation of the NF- $\mathrm{kB}$ pathway [20-21]. For this reason, modulation of NF- $\mathrm{KB}$ activation is the most important therapeutic strategy for reducing tissue damage that follows the release of inflammatory mediators. Therefore, the current study aimed at investigating the potential anti-NF- $\mathrm{\kappa B}$ and anti-inflammatory responses of $P$. turionellae venom on mammalian cells. Further, investigating the potential anti-inflammatory responses of an endoparasitoid wasp venom on mammalian cells will help to compare the differences and similarities between an ecto- and endoparasitoid species based on the finding of a previous study [4].

\section{Materials and methods}

\subsection{Insect rearing}

Idiobiont, solitary and endoparasitoid $P$. turionellae culture was reared on the host, greater wax moth, Galleria mellonella (Lepidoptera: Pyralidae) pupae [22]. Adult females and males were fed with 50\% (v:v) honey-water solution and pupae of G. mellonella (5 pupae for every 10 female wasps once every two days). Parasitoid culture was maintained at $24 \pm 1{ }^{\circ} \mathrm{C}, 55 \pm 5 \% \mathrm{RH}$, and 12: $12 \mathrm{~h}, \mathrm{~L}: \mathrm{D}$ photoperiod conditions in insect culture room (D-51) at Animal Physiology Laboratory, Eskisehir Technical University, Eskişehir, Turkey.

\subsection{Isolation of crude venom from P. turionellae}

Venom samples used for the experiments were isolated by removing the venom glands of 15 to 20 -day-old female wasps [22]. Venom glands of female wasps were used for each replicate of cell viability (MTT) and reporter 
gene analysis assays. Females were frozen at $-20^{\circ} \mathrm{C}$ for 10 minutes before dissection of venom glands. Then, venom glands were ruptured in distilled water and centrifuged at $12.000 \mathrm{~g},+4^{\circ} \mathrm{C}$ for $10 \mathrm{~min}$ to separate cell debris. The resultant supernatant was used as crude extract of the venom. These supernatants were transferred into clean microcentrifuge tubes and immediately lyophilized in a lyophilizer (Freeze dryer, Christ, model Alpha 1-4), frozen and stored at $-80^{\circ} \mathrm{C}$ until further use.

\subsection{Total protein analysis in crude venom}

Lyophilized crude venom samples were dissolved in insect saline buffer (ISB, $10 \mathrm{mM}$ Hepes, $2 \mathrm{mM} \mathrm{MgCl} 2,4$ $\mathrm{mM} \mathrm{CaCl} 2,10 \mathrm{mM} \mathrm{KCl}, 150 \mathrm{mM} \mathrm{NaCl}$ ) before analyzing the amount of total protein content. After suspension of the lyophilized crude venom, a total protein assay was performed according to the Bradford method at $595 \mathrm{~nm}$ using bovine serum albumin as the standard curve.

\subsection{Cell culture}

Mouse fibrosarcoma cells transfected with an NF-kB-dependent reporter gene (L929sA cells) were used in all experiments. L929sA cell lines were routinely grown on DMEM medium containing ten percent fetal bovine serum, 0.1 $\mathrm{mg} / \mathrm{ml}$ streptomycin and 100 units/ml penicillin supplements and maintained at $37{ }^{\circ} \mathrm{C}$ in $5 \% \mathrm{CO} 2$ humidified air. Cells were seeded with a density of 3000 cells/well 96 -well plates, 48 hours prior to treatment.

\subsection{MTT assay}

To determine the cytotoxicity of $P$. turionellae venom on the viability of L929sA cells, an MTT assay was performed using different concentrations of the venom and multiple incubation times (3, 7 and 24 hours). The MTT assay with L929sA cells was performed according to the protocol of Danneels et al. [4] using 3-(4,5-dimethylthiazol-2yl)-2,5-diphenyltetrazolium bromide (MTT, $0.5 \mathrm{mg} / \mathrm{ml}$ in each well. Subsequently, this plate was incubated at the same cell culture conditions as mentioned above. After this time period, $100 \mu$ l culture medium (without serum and antibiotics) in the negative control (NC), $100 \mu$ l deionized water or ISB in the positive control (PC) and $100 \mu 1$ culture medium without serum and antibiotics plus different concentrations of the wasp venom were added to the cell medium in the respective wells. After incubation (3, 7 and 24 hours) with different concentrations of venom $(0.08-40 \mu \mathrm{g} / \mathrm{ml})$, $20 \mu \mathrm{l}$ MTT solution $(0,5 \mathrm{mg} / \mathrm{ml})$ was added to each well in dark flow and incubated overnight in the dark at $37^{\circ} \mathrm{C}$ till blue deposits appeared. The formazan crystals were then dissolved in SDS/HCl solution and left to incubate at a temperature of $37^{\circ} \mathrm{C}$ for 5 hours. The absorbance was analyzed calorimetrically at $595 \mathrm{~nm}$ with a microplate reader (Apparatus Multiskan FC - Thermo Scientific). Based on this assay, nontoxic concentrations of wasp venom on the L929s A cells were determined to perform reporter gene analysis.

\subsection{Reporter gene analysis (Luciferase and $\beta$-galactosidase assay)}

Luciferase and $\beta$-galactosidase assays were performed as mentioned in Danneels et al. [4]. To examine the effects of the venom on NF-KB activity in this study, NF-KB-dependent reporter gene transfected L929sA cells (3.0 x 103 cells in each well) were seeded in a 96 well plate. Subsequently, these plates were incubated as cell culture conditions as mentioned above. After this time period, each well was pretreated with nontoxic concentrations of venom $(20,10,5,2.5,1.25,0.63$ and $0.32 \mu \mathrm{g} / \mathrm{ml})$ for 15 minutes and stimulated for 5 hours at 1000 and $2000 \mathrm{IU} / \mathrm{ml} \mathrm{TNF}$ concentrations. After incubation, all media were removed from each well and rinsed with phosphate buffer saline. Subsequently, $100 \mu \mathrm{l}$ lysis buffer (0.2 M K2HPO4, 0.2 M KH2PO4, 0.2 \% Triton X-100) was added to each well and frozen at $-80^{\circ} \mathrm{C}$ overnight. After freezing, cell lysates were thawed and $25 \mu 1$ of each cell lysate was loaded to black $96-$ well plates. For luciferase (luc) reporter assays, $50 \mu$ l luciferase mix (Sigma) was added per well to one plate and measured directly with luminometer (Viktor3 system, Perkin Elmer Life Sciences, Boston, MA). For galactosidase reporter assays, $50 \mu \mathrm{l}$ gal mix (Sigma) was added per well to the other plate and incubated for one hour. After incubation galactosidase activities in each plate were measured with luminometer (Viktor3 system, Perkin Elmer Life Sciences, Boston, MA). The b-galactosidase values were used to normalize the measured luciferase activity. Therefore, normalized NF-KB-dependent reporter gene activity was described as arbitrary light units.

\subsection{Statistical analysis}

All data were expressed as the mean \pm standard error (SE) of three replicates. Percentage data for cell viability were normalized by arcsine transformation before analysis. The SPSS software program (version 18.0 for Windows, SPSS Science, Chicago, IL) was used for all statistical analysis. First, Shapiro-Wilk test was used to confirm normality of the experimental results. All data were distributed normally. Therefore, our data was evaluated using analysis of 
variance (ANOVA) and separated using Least Significant Difference (LSD) and Dunnett's tests. Results were recorded as statistically significant when $\mathrm{P}<0.05$.

\section{Results}

\subsection{Cytotoxic effects of P. turionellae crude venom (MTT assay)}

Effects of isolated $P$. turionellae venom on cell viability of L929sA murine fibrosarcoma cells were determined by a cell viability (MTT) assay. As shown in figure 1, the percentage of cell viability changed according to both venom concentration and incubation time $(\mathrm{P}<0.05$, Dunett's test). After three hours of venom treatment, the viability of L929s A cells showed a statistically significant decrease of $17,8 \%(\mathrm{~F}=2.796 ; \mathrm{df}=10,22 ; \mathrm{P}=0.021)$, only at the highest concentration $(40 \mu \mathrm{g} / \mathrm{ml})$. After seven hours of venom exposure, lower venom concentrations had no significant effect on cell viability. Treatment with higher venom concentrations $(10,20$ and $40 \mu \mathrm{g} / \mathrm{ml})$ showed a statistically significant decrease in cell viability. Respectively $87.8 \%, 89.9 \%$ and $75,31 \%$, of the cells survived $(\mathrm{F}=8.639 ; \mathrm{df}=10,22 ; \mathrm{P}=$ $0,000)$. On the other hand, 24 hours post-incubation with $P$. turionellae venom, it was observed that even at the lower concentrations (from $1.25 \mu \mathrm{g} / \mathrm{ml}$ and above), cell viability decreased significantly when compared with other lower concentrations $(0,08-0,63 \mu \mathrm{g} / \mathrm{ml})$ and control $(\mathrm{F}=103.162 ; \mathrm{df}=10,22 ; \mathrm{P}=0.000)$. Cell viability $(\%)$ was reduced below $50 \%$ at the two highest venom concentrations after 24 hours incubation as shown in Figure 1.

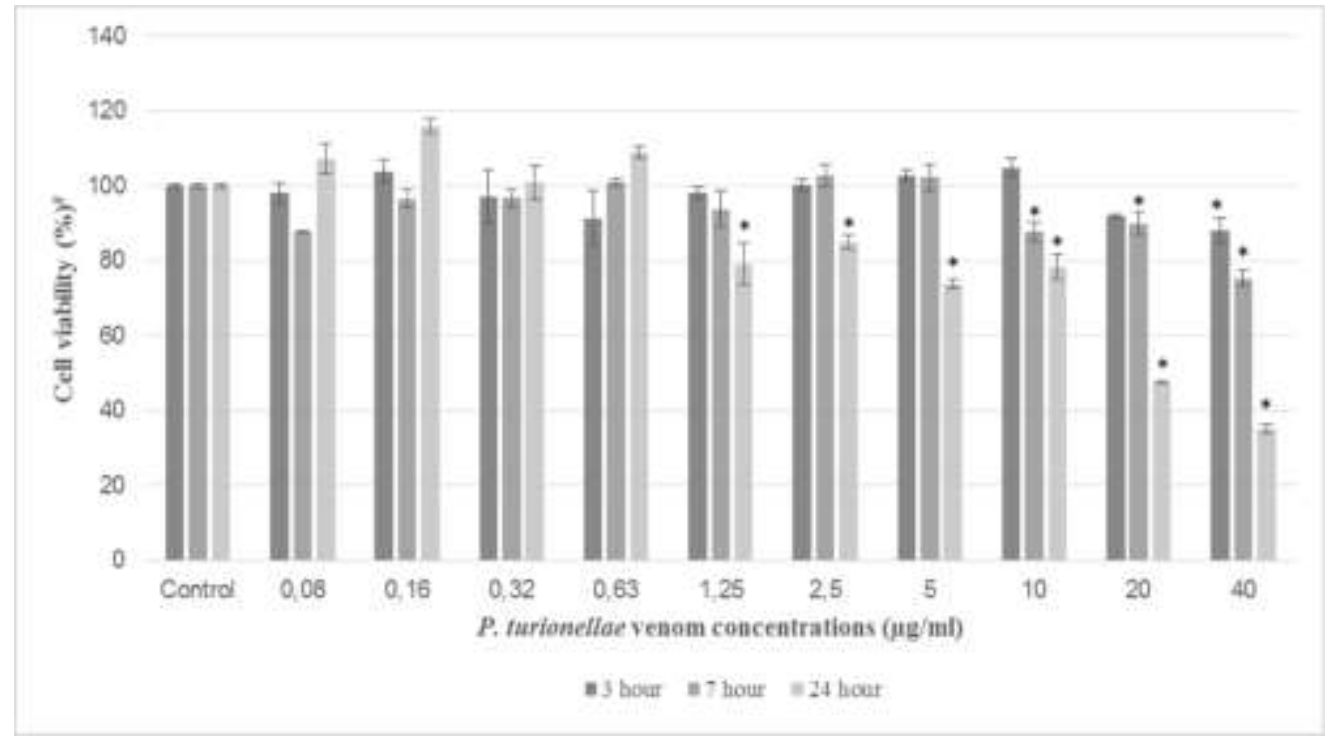

Figure 1. Influence of $P$. turionellae venom on L929sA murine fibrosarcoma cells viability (\%)

${ }^{\#}$ Cell viability was analyzed according to an MTT assay. Means of triplicates (\%) after respective treatments are shown in the graph together with the standard error (SE) bars. *Data were evaluated significantly different at a $95 \%$ confidence interval ( $\mathrm{p}<0.05$, Dunnett's tests).

\subsection{Effects of P. turionellae crude venom on NF- $\kappa B$ activity in TNF-stimulated L929sA cells}

According to MTT assay results, concentrations of venom at $0.32-20 \mu \mathrm{g} / \mathrm{ml}$ were nontoxic on cells within short incubation times. Therefore, these venom concentrations were used on cells for the NF- $\mathrm{B}$ activity analysis. In this analysis, a stably transfected NF- $\kappa \mathrm{B}$-dependent luciferase reporter gene system consisting of an NF- $\mathrm{BB}$-responsive element and a constitutively expressed reporter gene construct (pPGKbGeobpA) encoding $\beta$-galactosidase, was used to determine the effects of $P$. turionellae venom on TNF-dependent NF- $\kappa$ B activity in L929sA cells. Transfected L929sA cells were also stimulated with two different concentrations of TNF (1000 and $2000 \mathrm{IU} / \mathrm{ml}$ ) for five hours to induce the NF- $\kappa$ B reporter gene. While $\beta$-galactosidase activity did not change in both TNF-stimulated and unstimulated L929sA cells at all venom concentrations and control group, increased luciferase activity was observed in all TNF-stimulated groups compared with non-TNF-stimulated groups. These results obtained from $\beta$-galactosidase activities exhibited continued cell viability. Additionally, the luciferase activity measured in cells induced with TNF at $2000 \mathrm{IU} / \mathrm{ml}$ was determined to be higher than the cells stimulated with TNF at $1000 \mathrm{IU} / \mathrm{ml}$. Thus, luciferase and $\beta$-galactosidase activity results revealed that L929sA cells responded to TNF, followed by an induction of the NF- $\mathrm{BB}-$ reporter gene. After 5 hours of incubation with indicated TNF concentrations, luciferase activity significantly decreased with increased venom concentration in pre-treated cells compared to control $(\mathrm{P}<0.05$, Dunnett test). As shown in Figure 2, normalized NF- $\kappa \mathrm{B}$ dependent reporter gene activity decreased at $2.5-20 \mu \mathrm{g} / \mathrm{ml}$ venom concentrations when compared with lower venom concentrations and control $(\mathrm{F}=6.577 ; \mathrm{df}=7,16 ; \mathrm{P}=0.001$, LSD test $)$ in cells stimulated with $1000 \mathrm{IU} / \mathrm{ml} \mathrm{TNF}$ 
concentration. Whereas, at all venom concentrations, reporter gene activity decreased in comparison with control in $2000 \mathrm{IU} / \mathrm{ml}$ TNF-stimulated L929sA cells $(\mathrm{F}=9.656, \mathrm{df}=7,16, \mathrm{P}=0.000$, LSD test). Briefly, NF- $\mathrm{kB}$ dependent reporter gene activity in both 1000 and $2000 \mathrm{IU} / \mathrm{ml} \mathrm{TNF}$ stimulated L929sA cells was lowest at $10 \mu \mathrm{g} / \mathrm{ml}$ venom concentration compared to control cells.

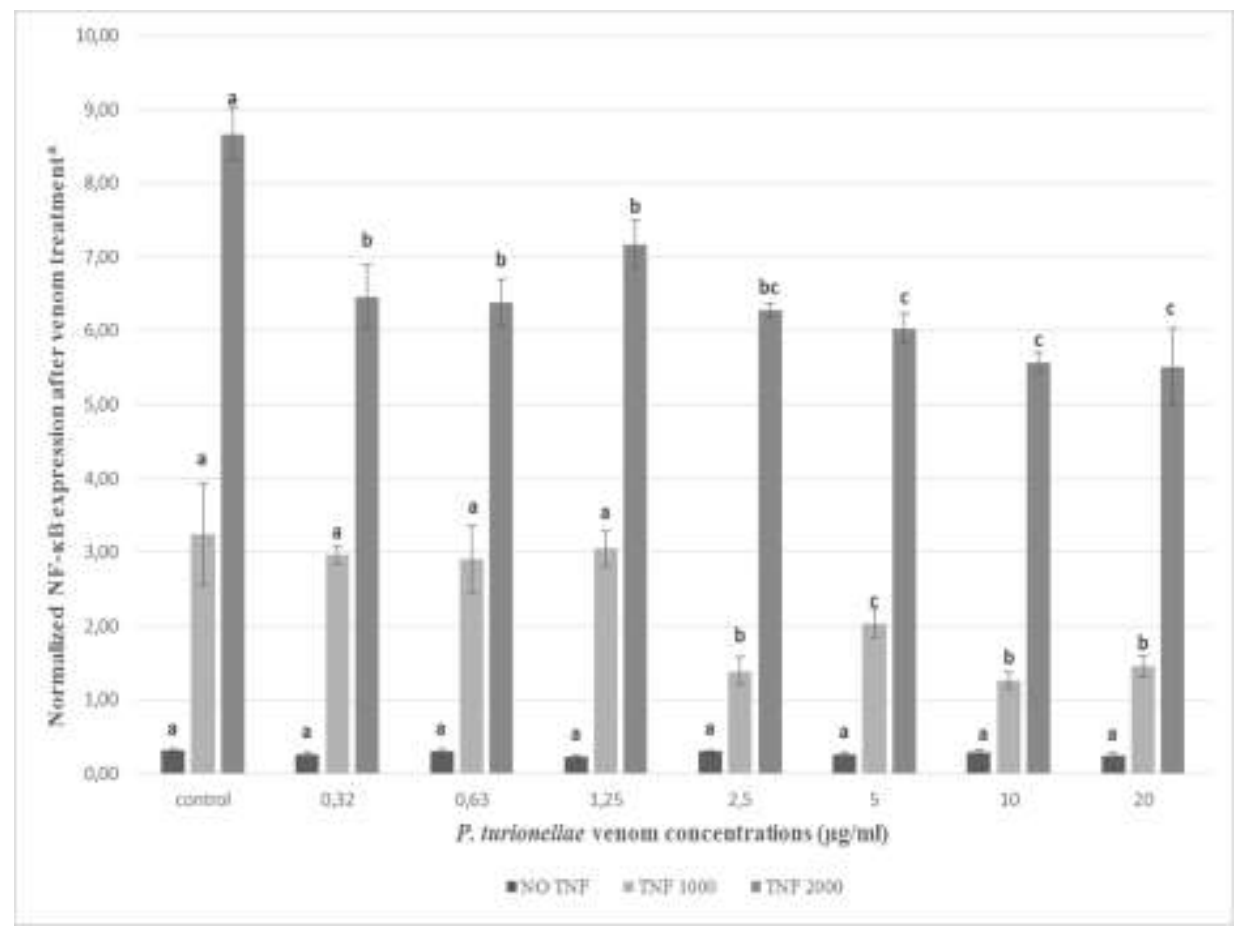

Figure 2. Influence of venom concentrations on TNF-dependent NF- $\kappa \mathrm{B}$ expression

*L929sA cells were seeded in 96 well plates and treated with different venom concentrations $(0.32-20 \mu \mathrm{g} / \mathrm{ml})$ and TNF $(1000-2000 \mathrm{U} / \mathrm{ml})$. Normalized NF- $\mathrm{kB}$ expression following treatment is shown as arbitrary light units. Means with SE fallowed by the different letters are significantly different ( $\mathrm{p}<0.05$, LSD test).

\section{Conclusions and discussion}

Cell death in host-parasitoid relationship is a general mechanism. This is often associated with the suppression of the host's immune system. Cell death may be caused by stimulation of the apoptotic or oncotic pathways by the secretions produced by the s female wasps such as venomous cocktails injected into the hosts [10, 23]. Thus, venoms from parasitoid species cause important physiological effects such as interrupting host immunity in parasitoid-host relationships. Previous studies reported that, solitary, idiobiont and endoparasitoid species, $P$. hypochondriaca and $P$. turionellae venoms' lack of PDV induced the paralyzation of their hosts via cytolytic and cytotoxic mechanisms [9, 1415, 24]. Er et al. [15] also showed that $P$. turionellae venom decreased cell viability, mitotic index, and encapsulation response of host hemocytes. Also, cell-mediated immune response was suppressed via inducing apoptotic or necrotic pathways in the larval and pupal stages of host $G$. mellonella. Furthermore, studies on the suppression of the immune system by endoparasitoid $P$. turionellae venom were performed on other insect cell cultures [15]. However, studies related with the effects of parasitoid venom on mammalian cells are limited in literature [4, 16, 25]. On the other hand, several studies demonstrated that bee venoms exhibit anticonvulsant [26], cytotoxic, genotoxic, mutagenic [27-28], antiinflammatory [29-30] and cytostatic [31] influences on the mammalian cells. Saba et al. [16] also argued that Hymenopteran venoms contain in them antimicrobial peptides which possess antibiotic activity against mammalian cells. Therefore, the current study was focused on investigating the potential cytotoxic and anti-inflammatory responses of endoparasitoid P. turionellae L. (Hymenoptera: Ichneumonidae) venom on mammalian cells. Our results show that venom can have cytotoxic effects on mammalian cells but mostly at longer incubation times and higher venom concentrations. Although in our experiment, at some point, significant decrease of cell viability is measured, it is not clear if this is biologically relevant since still $87 \%$ of the cells survive (Fig 1). Indeed, $P$. turionellae venom induces cell death in insect cell lines even at low concentrations [15], whereas in murine fibrosarcoma cells (L929sA), cytotoxicity was noticeable only at high doses $(20$ and $40 \mu \mathrm{g} / \mathrm{ml})$ and long induction time $(24 \mathrm{~h})$. Interestingly, these venom concentrations for mammalian cells are higher than concentrations determined for $N$. vitripennis and B. hebetor ectoparasitoid species venoms [4, 16]. As is evident from the results, ectoparasitoid venoms have higher toxicity potential than endoparasitoid venoms on mammalian cells. 
The second focus of this study was to investigate whether crude venom from $P$. turionella has inhibition potential on the NF- $\mathrm{KB}$ immune signaling pathway in L929sA cells stably transfected with a recombinant promoter that has an NF- $\kappa$ B-responsive element. According to cell viability results, venom from $P$. turionellae is not toxic at lower concentrations and shorter incubation periods. Thus, at 5 hours incubation period, $0.32-20 \mu \mathrm{g} / \mathrm{ml}$ venom concentrations appeared to be nontoxic to cells and these concentrations were used in reporter gene analysis to determine the antiinflammatory potential. In previous studies, it was reported that activation of NF- $\kappa$ B transcription factors and mitogen activated protein kinases (MAPK) pathways are evolutionarily conserved in metazoans [32, 33, 34, 35]. Danneels et al. [35] also suggested that ectoparasitoid $N$. vitripennis venom can modulate the NF- $\kappa$ B and MAPK pathways and thus, suppressing the immune response of the parasitized host Sarcopahaga crassipalpis pupae. Moreover, N. vitripennis venom at low concentrations $(0.4-12.5 \mu \mathrm{g} / \mathrm{ml})$ significantly decreased the relative luciferase activity in L929sA fibrosarcoma cells stimulated with TNF $(2000 \mathrm{IU} / \mathrm{ml}) 6$ hours post-exposure and thus, a concentration dependent venom-mediated suppression was shown in the NF- $\mathrm{BB}$ signaling pathway in mammalian cell lines, L929sA and Raw264.7 macrophages [4]. Similarly, venom from endoparasitoid P. turionellae decreased the normalized luciferase activity in these L929sA cells stimulated for five hours with two TNF concentrations (1000 and 2000 IU/ml) in this study. At the same time, increased luciferase activity was recorded at $2000 \mathrm{IU} / \mathrm{ml} \mathrm{TNF}$ concentration when compared to $1000 \mathrm{IU} / \mathrm{ml}$ TNF. However, normalized NF- $\mathrm{BB}-$ dependent promoter activities in L929sA cells did not decrease in a dose-dependent manner at all venom concentrations, in contrast to $N$. vitripennis venom [4]. In particular, NF- $\kappa \mathrm{B}$ dependent reporter gene activity in $2000 \mathrm{IU} / \mathrm{ml} \mathrm{TNF}$-stimulated L929s A cells decreased by approximately $36 \%$ at 10 $\mu \mathrm{g} / \mathrm{ml} P$. turionellae venom concentration compared to control cells. In addition, Saba et al. [16] demonstrated that crude venom from the ectoparasitoid wasp $B$. hebetor has anti-inflammatory activity in a dose dependent manner and suppresses the levels of proinflammatory mediators and cytokines via NF- $\kappa$ B and MAPK pathways in mammals both in vitro and in vivo. Same authors also suggested that $B$. hebetor venom can be evaluated as a nonsteroidal agent for the treatment of inflammatory diseases in the future. Together, the present and previous findings indicate that ectoparasitoid venom even at low concentrations has remarkable inhibitory effects on the NF- $\kappa \mathrm{B}$ signaling pathway in mammalian cells as compared to endoparasitoid venom. Keeping this mind, we suggest that these differences between endoparasitoid and ectoparasitoid venom may be related to a number of protein and polypeptide components. It is well known that crude venom from parasitoid wasps includes a high amount of toxins and manipulates cell physiology in diverse ways [25].

In conclusion, our results indicate that venom from $P$. turionellae has an anti-inflammatory potential on mammalian cells dependent on concentrations and exposure time. Therefore, further research on screening $P$. turionellae venom components responsible for possible anti-inflammatory characteristics with the aim of finding treatments for several chronic inflammatory diseases and cancer should be carried out to explore its molecular effects on the NF- $\mathrm{KB}$ signaling pathway.

\section{Acknowledgements}

This research was supported by the TUBITAK-FWO Joint Research Cooperation Project (Grant number: 115Z142). This research was also made possible by the funding of the Belgian Agency for Innovation by Science and Technology (IWT), project 141370.

\section{References}

[1] Tsai, S. H., Chen, Y. C., Chen, L., Wang, Y. M., \& Tsai, I. H. (2007). Binding of a venom Lys-49 phospholipase A (2) to LPS and suppression of its effects on Mouse macrophages. Toxicon, 50, 914-922.

[2] Park, H. J., Lee, H. J., Choi, M. S., Son, D. J., Song, H. S., Song, M. J., Lee, J. M., Han, S. B., Kim, Y., \& Hong, J. T. (2008). JNK pathway is involved in the inhibition of inflammatory target gene expression and NF-kappaB activation by melittin. Journal of Inflammation, 29, 5-7. https://doi: 10.1186/1476-9255-5-7

[3] Dkhil, M. A., Abdel-Baki, A. S., Al-Quraishi, S., \& Al-Khalifa, M. (2010). Anti-inflammatory activity of the venom from samsum ants Pachycondyla sennaarensis. African Journal of Pharmacy and Pharmacology, 4, 115118.

[4] Danneels, E. L., Gerlo, S., Heyninck, K., Van-Craenenbroeck, K., Bosscher, K., Haegeman, G., \& Graaf, D.C. (2014). How the Venom from the Ectoparasitoid Wasp Nasonia vitripennis Exhibits Anti-Inflammatory Properties on Mammalian Cell Lines. Plos-One, 9 (5), e96825.

[5] Beckage, N. E. (1993). Games parasites play: The dynamic roles of proteins and peptides in the relationship between parasite and host. In N. E. Beckage, S. N. Thompson \& B. A. Federici (Eds), Parasites and Pathogens of Insects (pp. 25-57). Academic Press.

[6] Thompson S. N. (1993). Redirection of host metabolism and effects on parasite nutrition. In N. E. Beckage, S. N. Thompson \& B. A. Federici (Eds), Parasites and Pathogens of Insects (pp. 125-144). Academic Press. 
[7] Rivers, D. B., Ruggiero, L., \& Hayes, M. (2002). The ectoparasitic wasp Nasonia vitripennis (Walker) (Hymenoptera: Pteromalidae) differentially affects cells mediating the immune response of its flesh fly host, Sarcophaga bullata Parker (Diptera: Sarcophagidae). Journal of Insect Physiology, 48, 1053-1064.

[8] Rivers, D. B., Uckan, F., Ergin, E., \& Keefer, D.A. (2010). Pathological and ultrastructural changes in cultured cells induced by venom from the ectoparasitic wasp Nasonia vitripennis (Walker) (Hymenoptera: Pteromalidae). Journal of Insect Physiology, 56, 1935-1948.

[9] Keenan, B., Uçkan, F., Ergin, E., \& Rivers, D. B. (2007). Recent Advances in the Biochemistry, Toxicity, and Mode of Action of Parasitic Wasp Venoms. In D. Rivers \& J. Yoder (Eds), Morphological and biochemical changes in cultured cells induced by venom from the endoparasitoid, Pimpla turionellae (Chapter 5, pp. 75-92). Research Signpost, Fort P.O., Trivandrum-695 023, Kerala, India.

[10] Asgari, S. \& Rivers, D. B. (2011). Venom proteins from endoparasitoid wasps and their role in host-parasite interactions. Annual Review of Entomology, 56, 313-335.

[11] Gueguen, G., Kalamarz, M. E., Ramroop, J., Uribe, J., \& Govind, S. (2013). Polydnaviral Ankyrin Proteins Aid Parasitic Wasp Survival by Coordinate and Selective Inhibition of Hematopoietic and Immune NF-kappa B Signaling in Insect Hosts. PLoS Pathogology, 9. https://doi:10.1371/journal.ppat.1003580

[12] Zhang, G. M., Schmidt, O., \& Asgari, S. A. (2006). Calreticulin-like protein from endoparasitoid venom fluid is involved in host hemocyte inactivation. Developmental \& Comparative Immunology, 30, 756-764.

[13] Uçkan, F., Sinan S., Savasci S., \& Ergin E. (2004). Determination of venom components from the endoparasitoid wasp Pimpla turionellae L. (Hymenoptera: Ichneumonidae). Annals of the Entomological Society of America , 97, 775-780.

[14] Ergin, E., Uçkan, F., Rivers, D. B., \& Sak, O. (2006). In vivo and in vitro activity of venom from the endoparasitic wasp Pimpla turionellae (L.) (Hymenoptera: Ichneumonidae). Archives of Insect Biochemistry and Physiology, 61 (2), 87-97.

[15] Er, A., Sak, O., Ergin, E., Uçkan, F., \& Rivers, D. B. (2011). Venom induced immuno-suppression: An overview of hemocyte mediated responses. Psyche, Article ID 276376, 14 pages. https://doi:10.1155/2011/276376

[16] Saba, E., Shafeeq, T., Irfan, M., Lee, Y.Y., Kwon, H. W., Seo, M. G., Park, S. J., Lee, K. Y., \& Rhee, M. H. (2017). Anti-Inflammatory Activity of Crude Venom Isolated from Parasitoid Wasp, Bracon hebetor Say. Mediators Inflammatory. https://doi.org/10.1155/2017/6978194

[17] Hoffmann, J. A., Kafatos, F. C., Janeway, C. A., \& Ezekowitz, R. A. (1999). Phylogenetic perspectives in innate immunity. Science, 284, 1313-1318.

[18] Kimbrell, D. A. \& Beutler, B. (2001). The evolution and genetics of innate immunity. Nature Reviews Genetics, 2, 256-267.

[19] Yamamoto, Y. \& Gaynor, R. B. (2001). Therapeutic potential of inhibition of the NFkappa B pathway in the treatment of inflammation and cancer. Journal of Clinical Investigation, 107, 135-142.

[20] Kumar, A., Takada, Y., Boriek, A. M., \& Aggarwal, B. B. (2004). Nuclear factor-kappa B: its role in health and disease. Journal of Molecular Medicine, 82, 434-448.

[21] Di-Donato, J. A., Mercurio, F., \& Karin, M. (2012). NF-kappaB and the link between inflammation and cancer. Immunological Reviews, 246, 379-400.

[22] Ergin, E., Altuntaş, H., \& Uçkan F. (2013). Effects of parasitization and envenomation by the endoparasitic Wasp Pimpla turionellae L. (Hymenoptera: Ichneumonidae) on hemolymph protein profile of its host Galleria mellonella L. (Lepidoptera: Pyralidae). Biological Diversity and Conservation, 6 (1), 62-70.

[23] Moreau, S. J. \& Asgari, S. (2015). Venom proteins from parasitoid wasps and their biological functions. Toxins, 7 (7), 2385-2412.

[24] Parkinson, N. M., \& Weaver R. J. (1999). Noxious components of venom from the pupaspecific parasitoid Pimpla hypochondriaca. Journal of Invertebrate Pathology, 73, 74-83.

[25] Danneels, E. L., Formesyn, E. M., \& de Graaf, D.C. (2015). Exploring the Potential of Venom from Nasonia vitripennis as Therapeutic Agent with High-Throughput Screening Tools. Toxins, 7, 2051-2070.

[26] Cunha, A. O. S., Mortari, M. R., Oliveira, L., Oliveira, R., Carolino, G., Coutinho-Netto, J., \& dos Santos, W. F. (2005). Anticonvulsant effects of the wasp Polybia ignobilis venom on chemically induced seizures and action on GABA and glutamate receptors. Comparative Biochemistry and Physiology Part C, 141(1), 50-57.

[27] Hoshina, M. M., Santos, L. D., Palma, M. S., \& Marin-Morales, M. A. (2013). Cytotoxic, genotoxic/antigenotoxic and mutagenic/ antimutagenic effects of the venom of the wasp Polybia paulista. Toxicon, 72, 64-70. 
[28] Sisakht, M., Mashkani, B., Bazi, A., Ostadi, H., Zare, M., Avval, F.Z., Sadeghnia, H.R., Mojarad, M., Nadri, M., Ghorbani, A., \& Soukhtanloo, M. (2017). Bee venom induces apoptosis and suppresses matrix metaloprotease-2 expression in human glioblastoma cells. Revista Brasileira de Farmacognosia, 27, 324-328.

[29] Im, E. J., Kim, S. J., Hong, S.B., Park, J. K., \& Rhee, M. H. (2016). Anti-inflammatory activity of bee venom in BV2 microglial cells: Mediation of MyD88-dependent NF- $\kappa \mathrm{B}$ signaling pathway. Evidence-Based Complementary and Alternative, Article ID 3704764. https://doi: 10.1155/2016/3704764

[30] Nipate, S.S., Hurali, P.B., \& Ghaisas, M.M. (2015). Evaluation of anti-inflammatory, anti-nociceptive, and antiarthritic 10 Mediators of Inflammation activities of Indian Apis dorsata bee venom in experimental animals: biochemical, histological, and radiological assessment. Immunopharmacology and Immunotoxicology, 37 (2), 171-184.

[31] Liu, X., Chen, D., Xie, L., \& Zhang, R., (2002). Effect of honeybee venom on proliferation of K1735M2 mouse melanoma cells in-vitro and growth of murine B16 melanomas in-vivo. Journal of Pharmacy and Pharmacology, 54 (8), 1083-1089.

[32] Lim, Y. M., Nishizawa, K., Nishi, Y., Tsuda, L., Inoue, Y. H., \& Nishida Y. (1999). Genetic analysis of rolled, which encodes a Drosophila mitogen-activated protein kinase. Genetics, 153 (2), 763-771.

[33] Hatada, E. N., Krappmann, D., \& Scheidereit, C. (2000). NF-kappa B and the innate immune response. Current Opinion in Immunology, 12, 52-58.

[34] Inoue, H., Tateno, M., Fujimura-Kamada, K., Takaesu, G., Adachi-Yamada, T., Ninomiya-Tsuji, J., Irie, K., Nishida, Y., \& Matsumoto, K. A. (2001). Drosophila MAPKKK, D-MEKK1, mediates stress responses through activation of p38 MAPK. The EMBO Journal, 20 (19), 5421-30.

[35] Danneels, E. L., Formesyn, E. M., Hahn, D. A., Denlinger, D. L., Cardoen, D., Wenseleers, T., Schoofs, L., \& de Graaf, D.C. (2013). Early changes in the pupal transcriptome of the flesh fly Sarcophagha crassipalpis to parasitization by the ectoparasitic wasp, Nasonia vitripennis. Insect Biochemistry and Molecular Biolology, 43, 1189-1200. 